\title{
Remote Sensing for Agricultural Crops Based on a Low Cost Quadcopter
}

\author{
Liseth Viviana Campo Arcos, M.Sc.(c) / liscampo@unicauca.edu.co \\ Juan Carlos Corrales Muñoz, Ph.D. / jcorral@unicauca.edu.co \\ Agapito Ledezma Espino, Ph.D. / ledezma@inf.uc3m.es
}

ABSTRACT This paper presents a proposal for information gathering from crops by means of a low-cost quadcopter known as the AR Drone 2.0. To achieve this, we designed a system for remote sensing that addresses challenges identified in the present research, such as acquisition of aerial photographs of an entire crop and AR Drone navigation on non-planar areas arises. The project is currently at an early stage of development. The first stage describes platform and hardware/software tools used to build the proposed prototype. Second stage characterizes performance experiments of sensors stability and altitude in AR Drone, in order to design an altitude strategy control over non-flat crops. In addition, path planning algorithms based on shortest route by graphs (Dijkstra, $\mathrm{A}^{*}$ and wavefront propagation) are evaluated with simulated quadcopter. The implementation of the shortest path algorithms is the beginning to full coverage of a crop. Observations of quadcopter behavior in Gazebo simulator and real tests demonstrate viability to execute the project by using AR Drone like platform of a remote sensing system to precision agriculture.

KEYWORDS Cuadricóptero; teledetección; agricultura de precisión; AR Drone; control de altura; planifi-cador de ruta.

\section{Teledetección para cultivos agrícolas ba- sada en un cuadricóptero de bajo costo}

RESUMEN Este artículo presenta una propuesta para recolectar información de cultivos agrícolas mediante un cuadricóptero de bajo costo, llamado AR Drone 2.0. Para lograr el objetivo se diseña un sistema de teledetección que enmarca desafíos identificados en la presente investigación, tales como, la adquisición de fotografías aéreas de todo un cultivo y la navegación del AR Drone en zonas no planas. El proyecto se encuentra en una fase temprana de desarrollo. La primera etapa indaga la plataforma y las herramientas hardware y software para construir el prototipo propuesto; la segunda, describe los experimentos de desempeño de los sensores de estabilidad y altura del AR Drone, con el fin de diseñar una estrategia de control de altura en cultivos no planos. Además, se evalúan algoritmos de planificación de ruta basados en la ruta más corta mediante grafos (Dijkstra, A* y propagación de frente de onda) usando un cuadricóptero simulado. La implementación de los algoritmos de la ruta más corta es el comienzo de la cobertura total de un cultivo. Las observaciones del comportamiento del cuadricóptero en el simulador Gazebo y las pruebas reales, demuestran la viabilidad de ejecutar el proyecto, usando el AR Drone como plataforma de un sistema de teledetección para agricultura de precisión.

PALABRAS CLAVE Guadricóptero; teledetección; agricultura de precisión; AR Drone; control de altura; planificador de ruta.
Sensoriamento remoto para culturas agrícolas baseado em um quadricóptero de baixo custo

RESUMO Este artigo apresenta uma proposta para a coleta de informações sobre as culturas agrícolas utilizando um quadricóptero de baixo custo, chamado AR Drone 2.0. Para atingir o objetivo proposto foi desenhado um sistema de sensoriamento remoto que determina desafios, tais como a aquisição de fotografias aéreas de toda a colheita e a navegação do AR Drone em áreas não planas. $\mathrm{O}$ projeto está atualmente na sua fase de desenvolvimento. A primeira fase examina a plataforma e as ferramentas de hardware e de software necessárias para construir o protótipo proposto; a segunda fase descreve os experimentos de desempenho da estabilidade e da altura do AR Drone, a fim de conceber uma estratégia para o controle de altura em colheitas não planas; aliás, são avaliados algoritmos de planificação de rota com base na rota mais curta mediante grafos (Dijkstra, A *, e propagação da frente de onda) usando um quadricóptero simulado. A implementação dos algoritmos da rota mais curta é o início da cobertura total de uma colheita. Tanto as observações do comportamento do quadricóptero no simulador Gazebo, como os testes reais, demonstram a viabilidade de implementar o projeto usando o AR Drone como uma plataforma para um sistema de sensoriamento remoto para a agricultura de precisão.

PALAVRAS-CHAVE Quadricóptero, Sensoramento remoto, Agricultura de precisão, AR Drone, Controle de altura, Planificador de rota. 


\section{Introduction}

Unmanned Aerial Vehicles (UAV) offer serious opportunities in the design of systems intended to measure and obtain physical and chemical properties of several phenomena. This new technological approach is the result of platforms characteristics, with multiple sensors, capable of achieving object features with a higher level of detail. The reach of these UAV is related to remote sensing, which is a method of obtaining information without direct contact by using devices such as cameras, lasers, radiofrequency $(\mathrm{RF})$ receivers, radars, sonars, and magnetometers. Precision agriculture is one of the remote sensing related areas, since agricultural labor requires acquisition, processing, and interpretation of higher data volumes coming from broad areas in a very precise way (Joseph, 2005). Precision agriculture relies on remote sensing to manage resources efficiently in adequate place, time, and moment; avoiding economic loss (Bongiovanni \& Lowenberg-Deboer, 2004). Remote sensing allows data gathering of temporal and spatial variability of plants, soil, and environment parameters. These variability parameters are obtained from photograph mosaics by analyzing the electromagnetic spectrum with the aim of obtaining vegetation indices and, consequently, determining real condition of crops. In consequence, this leads to the establishment of damage and/or evolution in crop periods (i.e. sowing, growing, maturing, and harvesting, among others), and medium range diagnoses (Ji-hua \& Bing-fang, 2008).

Under the precision agriculture domain, remote sensing systems that include several UAV types are used. Most of these UAVs weigh between 1 and 20 kilograms and reach altitudes up to 900 meters, depending on their payload. $\mathrm{Cu}$ rrently, trends using these devices follow features previously presented, due to their ease of modeling and operation together with their low cost. To illustrate some examples, Carolo P330 UAV was one of the first aerial devices used in crop photogrammetry; it is a fixed wing device with manual control and GPS-based autopilot (Grenzdorffer, Engel, \& Teichert, 2008). Helicopter-shaped models are also used in agricultural tasks, managing to capture georeferenced images using GPS and specialized payload such as the Febry-Perot interferometer (Sugiura, Noguchi, \& Ishii, 2005). However, robots with multiple rotors (i.e. quadcopters, hexacopters, octocopters, etc.) are the most popular UAVs in agricultural labor and their use to obtain vegetation indices and crop mapping is increasing.

\section{Introducción}

Las aeronaves no tripuladas conocidas como VANT [vehículos aéreos no tripulados] ofrecen grandes oportunidades en el diseño de sistemas para la medición y el registro de propiedades físicas y químicas de fenómenos u objetos en áreas extensas. Este nuevo enfoque tecnológico se debe a que las plataformas están dotadas con múltiples sensores, mediante los cuales es posible conseguir características de los objetos con mayor detalle. El alcance de estos vehículos aéreos está reflejado en la teledetección, entendiéndola como un método para obtener información de las propiedades sin contacto directo, con dispositivos tales como cámaras, láser, receptores de radiofrecuencia, radares, sonares y magnetómetros. La agricultura de precisión es uno de los campos de acción de la teledetección, ya que las prácticas agrícolas requieren la adquisición, el procesamiento y la interpretación de una gran cantidad de datos, de manera precisa, de extensas áreas (Joseph, 2005). La agricultura de precisión se apoya en la teledetección para gestionar eficientemente los recursos en el lugar, tiempo y momento adecuados, evitando pérdidas económicas y productivas (Bongiovanni \& Lowenberg-Deboer, 2004). La teledetección permite la adquisición de datos de la variabilidad temporal y espacial de parámetros de plantas, suelo y ambiente. Dicha variabilidad se puede obtener mediante mosaicos de fotografías en los cuales se analiza el espectro electromagnético, para obtener los índices de vegetación y determinar las condiciones reales de cultivos. De esta forma se establece el deterioro y/o evolución en periodos de tiempo, la etapa de crecimiento (siembra, maduración, cosecha, entre otras) y un diagnóstico de mediano alcance (Ji-hua \& Bing-fang, 2008).

En el dominio de la agricultura de precisión se utilizan sistemas de teledetección que integran diferentes tipos de VANT, que en su mayoría tienen pesos entre 1 y 20 kilogramos, y alturas de operación de 3 a 900 metros, dependiendo de su capacidad de carga útil. La tendencia hacia vehículos aéreos con dichas características se genera gracias a su fácil modelado y operación, y a su bajo costo. Por nombrar algunos ejemplos, Carolo P330 es de los primeros vehículos aéreos para los procesos de fotogrametría de cultivos agrícolas. Carolo es un modelo de ala fija, de control manual y autopiloto usando GPS (Grenzdorffer, Engel, \& Teichert, 2008). Los modelos de helicópteros también son considerados para las tareas agrícolas, logran capturar imágenes georreferenciadas usando GPS y cuentan con carga útil especializada como las cámaras basadas en el interferómetro de Febry Perot (Sugiura, Noguchi, \& Ishii, 2005). Sin embargo son las aeronaves de tipo helicóptero, con múltiples rotores, las que han ganado protagonismo en los últimos años, por lo que son utilizadas frecuentemente para obtener diferentes índices de vegetación y mapeo de los cultivos.

Turner, Lucieer, y Watson (2011) describen un sistema para viticultura de precisión que utiliza un octocóptero con cámara digital Canon, un arreglo Tetracam con filtros en 
seis bandas y una cámara térmica infrarroja. El sistema se despliega durante cinco minutos en Richmond al sur de Tasmania, siguiendo una trayectoria sobre celdas con resolución de 200x100 metros. El trabajo realiza una evaluación de algoritmos para el procesamiento de orto-mosaicos en cada espectro. Primicerio et al. (2012) despliegan un sistema para teledetección de un viñedo en el centro de Italia, con un Mikropkopter de seis rotores, denominado VIPtero. El robot aéreo es tele-operado por diez minutos, portando una cámara multi-espectral, para la obtención de una gran cantidad de índices de vegetación. Otro trabajo con la configuración de seis rotores, pero en el espectro de color (RGB), es el sistema FlightCopter. Este vehículo aéreo es operado sobre cultivos de avena y arveja ubicados en una granja al norte de Hesse en Alemania, con alturas de vuelo de 30 metros, en aproximadamente 10 minutos. Con el sistema se logra calcular el índice diferencial normalizado para relacionar la biomasa sobre el suelo y el índice del área de la hoja en toda la granja (Jannoura, Brinkmann, Uteau, Bruns, \& Joergensen, 2015). Un trabajo representativo de teledetección con imágenes digitales capturadas con cuadricópteros utiliza el robot MD4-1000, con el cual obtiene orto mosaicos de cultivos de trigo ubicados en Sevilla (España), para diferenciar la maleza (Gómez-Candón, De Castro, \& López-Granados, 2014).

Para el presente proyecto se ha seleccionado AR Drone como plataforma aérea, debido a su bajo costo, los sensores y su valor agregado en cuanto a estabilidad, dado que usa técnicas de visión para la estimación del posicionamiento. AR Drone es un cuadricóptero fabricado por la empresa Parrot S.A., quien desde hace más de cinco años ha tenido gran auge en todo el mundo por su enfoque en la realidad aumentada. AR Drone 2.0 tiene un control basado en la variación de la velocidad de cuatro rotores adheridos a una cruz simétrica y está conformado por una variedad de sensores, como acelerómetros, giróscopos, sonar, sensor de presión y cámaras (baja y frontal en alta definición), que de manera similar al resto de aeronaves no tripuladas, están modelados físicamente mediante seis grados de libertad: $x$, $\mathrm{y}, \mathrm{z}$, roll (giro con respecto al eje $\mathrm{x}$ ), pitch (giro con respecto al eje y) y yaw (giro con respecto al eje z). Dichos parámetros establecen el posicionamiento relativo, la velocidad y la orientación del robot aéreo. AR Drone 2.0 puede tener un vuelo continuo de quince minutos y una capacidad de carga máxima de 100 gramos. Además, puede ser operado inalámbricamente mediante Wi-Fi con una aplicación móvil o software de escritorio (Bristeau, Callou, Vissiere, \& Petit, 2011). Las aplicaciones con AR Drone se extienden, no solo en el ámbito de entretenimiento, sino también en salud, obras civiles, vigilancia de vehículos y servicios domiciliarios, entre otros, debido a que su portabilidad y licencia para desarrollo libre, permiten converger diferentes tecnologías como Kinect, GPS y Smartphone, para generar diferentes funcionalidades que asistan las actividades humanas en diferentes aspectos de la cotidianidad.
Turner, Lucieer, and Watson (2011) describe a precision viticulture system that uses an octocopter with a Canon ${ }^{\circledR}$ digital camera, a Tetracam $®$ multi-camera array with filters in six bands, and a thermal infrared camera. The system was deployed for 5 minutes in $\mathrm{Ri}$ chmond (Tasmania, Australia) following a cell-shaped trajectory with 200x100 meters resolution. The research project evaluates several algorithms capable of processing ortho-mosaics in each spectrum band. Primicerio et al. (2012) use a remote sensing system designed for vineyards in Italy and based on a micro-copter called VIPtero. The aerial robot is remotely operated for $10 \mathrm{mi}-$ nutes, carrying a multispectral camera to get several vegetation indices. Another research project with a six-rotor configuration, but in color spectrum bands (RGB), is the FlightCopter system. This UAV flies over oats and peas fields located in Hesse, Germany, flying at an elevation of 30 meters and approximately for 10 minutes. With this configuration, authors were able to calculate a normalized differential index to connect ground biomass with the leaf area index in the whole farm (Jannoura, Brinkmann, Uteau, Bruns, \& Joergensen, 2015). A representative work in remote sensing systems using quadcopters employs MD4-1000 UAV; it acquires ortho-mosaics from wheat located in Seville (Spain), differentiating weeds from crops (Gómez-Candón, De Castro, \& López-Granados, 2014).

For the present work, we selected the AR Drone as aerial platform given its low cost, sensors and remarkable stability (i.e. it uses vision techniques to estimate positioning). The AR Drone is a quadcopter manufactured by Parrot ${ }^{\circledR}$ who have had experience in augmented reality for over 5 years. The AR Drone 2.0 has a control based on speed variation of four rotors added into a cross-shaped symmetric structure and it features several sensors such as the accelerometer, gyroscope, sonar, pressure sensor, and cameras (low and frontal in high definition). Similar to other UAVs, cameras in the AR Drone are physically modeled by six degrees of freedom: "x", "y", "z", "roll", "pitch", and "yaw", where roll, pitch, and yaw are turns in the "x", " $y$ ", and "z" axes respectively. These parameters set relative positioning, speed, and orientation of aerial robot. The AR Drone 2.0 has a top-flight time of 15 minutes and a maximum payload of 100 grams; in addition, operation through Wi-Fi from smartphones or laptops is possible (Bristeau, Callou, Vissiere, \& Petit, 2011). The applications of the AR Drone 
(and UAV in general) are not only for entertainment, but also for health purposes, civil constructions, vehicle surveillance, domiciliary services, and so on. Because of its portability and free development license, the AR Drone allows the convergence of several technologies like Kinect, GPS, and others presented in smartphones, helping with various common activities. In the agricultural field, we could not find related work using this Parrot ${ }^{\circledR}$ technology and device in lands and fields. This is because the construction of the AR Drone is not suitable for wild and rough environments (i.e. its performance might be seriously affected); furthermore, its size and weigh prevent it from being controlled at long distances without damage concerns. Conversely, the AR Drone is ideal to build a remote sensing prototype capable of verifying the design of the proposed system in this document.

As mentioned previously, the general purpose of this project is building a low-cost remote sensing system capable of mapping crops and cultivation precisely. With the purpose of achieving this goal, aerial robot should sample desired crops accurately using aerial photography. A route planner is required to gather complete and precise data from crops. In consequence, software platforms to manage the navigation of UAVs through GPS are essential in this project. These platforms have modules, which select points on a map (usually Google ${ }^{\circledR}$ Maps) and send desired route to the UAV. For instance, QGroundControl is a control station software that connects various autopilots of several UAV types thanks to the MAVLink protocol (Qgroundcontrol.org, 2009). Mission Planner and APM Planner are two software suites that are capable of controlling UAV flight and actual state remotely, as long as the autopilot type is ArdupilotMega or Pixhawk (Open Source Autopilot, 2015). Paparazzy is an open source project known for its control over the AR Drone and Bebop UAV, besides autopilots based on this project. Additionally, there are proper optimized platforms based on application features and developers interests. An interesting case is Naza-M: the main ground control application for the DJI® Phantom quadcopter. In the agricultural field, there is a useful software suite capable of capturing spatial monitoring and diagnosis (Agribotix, 2015). Route planners are also part of the robot coordination tendencies for UAV use in remote sensing systems. Joao Valente details a three-quadcopter system in a farm located in Spain; platforms used in this study were AR 100 and Ast Tec Hummingbird (Valente, 2011).
En cuanto a la agricultura, el presente estudio no ha encontrado trabajos relacionados que precisen el uso de esta plataforma para entornos agrícolas. Esto se debe a que no ha sido diseñado para ambientes agrestes y su desempeño puede verse gravemente afectado; además, su tamaño y peso le impiden navegar a grandes distancias de la estación de control sin temor a posibles pérdidas o daños de la plataforma. Sin embargo, AR Drone es un robot aéreo ideal para construir un prototipo de teledetección con el cual se verifique el alcance del diseño del sistema propuesto en este documento.

De acuerdo con lo mencionado, el propósito general del proyecto es construir un sistema de teledetección de bajo costo para realizar un mapeo preciso de cultivos agrícolas. Para lograrlo, el robot aéreo debe realizar un muestreo completo de un cultivo, que para el caso particular se realiza mediante fotografías aéreas. Para una recolección completa y precisa de datos del cultivo, se requiere un planificador de ruta. En este sentido, hay algunas plataformas software que gestionan la navegación de robots aéreos integrados con GPS. Estas plataformas disponen de un módulo que selecciona puntos de paso sobre un mapa (generalmente desde Google Maps), los cuales son enviados al vehículo aéreo como la ruta a seguir. Como ejemplos QGroundControl es un software de estación de control que puede conectar varios autopilotos de diferentes tipos de vehículos aéreos, mediante el protocolo MAVLink (Meier et al., 2010). Mission Planner y APM Planner son software que se pueden controlar de manera remota y registrar el estado de diferentes tipos de VANT multi-rotor o aeroplanos, siempre y cuando tengan ArdupilotMega o Pixhawk como autopiloto (ArduPilot..., s.f). Paparazzy es un proyecto de fuente abierta al igual que los anteriores. Es conocido porque permite el control de Ar Drone y Bebop, además de los autopilotos base para dicho proyecto. Adicionalmente existen plataformas propietarias optimizadas de acuerdo con la aplicación e intereses de los desarrolladores. Un caso sobresaliente es Naza-M, la principal aplicación de control en tierra para el cuadricóptero DJI Phantom. En el campo de la agricultura existe software de estación base especializado en captar información útil para monitoreo espacial y diagnóstico, como se aprecia en Agribotix (2015). Las nuevas tendencias de coordinación de robots para teledetección de cultivos también forman parte de los planificadores de ruta. Joao Valente (2011) detalla un sistema con tres cuadricópteros en una granja de España, usando plataformas AR 100 y Ast Tec Hummingbird.

El contenido descrito a continuación incluye: la sección II, que describe la metodología para la implementación del sistema de teledetección; la sección III, que detalla los resultados de pruebas experimentales; y la sección IV, que plantea las conclusiones de la propuesta presentada.

\section{Metodología}

Con base en el contexto de la sección introductoria y en conjunto con las referencias bibliográficas indagadas en el 
transcurso del planteamiento de la presente propuesta, se identificaron algunos retos particulares en el desarrollo de este tipo sistemas para la agricultura. El primero, la limitada capacidad de carga útil, por la que portar sensores adicionales implica menor rendimiento en la plataforma; el segundo, el corto tiempo de vuelo, ya que las plataformas no tienen energía por más de 15 minutos; el tercero, la configuración de los robots, la cual considera condiciones ideales del entorno, es decir una velocidad del viento despreciable, cultivos planos y días despejados; y cuarto, el alcance limitado de planificadores de ruta comerciales, ya que en su mayoría son manuales, por lo cual no precisan en condiciones de área, tiempo y número de puntos de paso apropiado. A continuación se describen las etapas plateadas para desarrollar el prototipo de la propuesta.

\section{A. Formulación del problema}

La teledetección con robots aéreos ha superado las restricciones de la teledetección tradicional en cuanto a costo y manejo de múltiples sensores, permitiendo adquirir información detallada de variables fisicoquímicas en cualquier lugar y momento. Sin embargo, la teledetección de cultivos basado en vehículos aéreos está limitada por varios factores: el corto tiempo de vuelo; la inevitable pérdida de información en caso de fallas; y el hecho de haber sido consideradas solo para áreas planas. Por tanto el trabajo está orientado a la implementación de un sistema de bajo costo para monitorizar, espacial y temporalmente, un cultivo agrícola mediante imágenes (FIGURA 1). El sistema debe obtener información confiable y completa de un cultivo, para lo cual es necesario considerar características como el relieve del área de cobertura y el tiempo de vuelo limitado del AR Drone.

Para abordar el problema se siguen tres objetivos particulares: adaptar la plataforma a las características de los cultivos, para lo cual es necesario optimizar el posicionamiento del AR Drone en ambientes abiertos; obtener información completa del cultivo, mediante una planificación de ruta que considere las limitaciones del cuadricóptero; y optimizar el sistema para obtener imágenes confiables integrando las metas anteriores.

\section{Capa de Gestión}

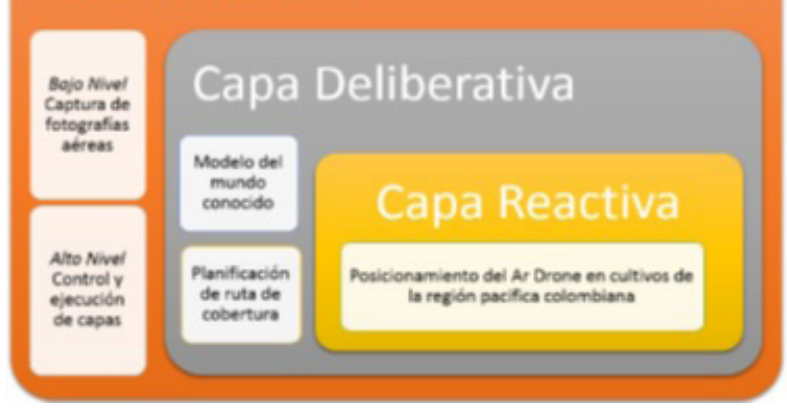

Figure 1. Remote sensing system for agricultural crops / Figura 1. Sistema de teledetección para cultivos agrícolas
The rest of this document is structured as follows: section II describes the methodology for system implementation, section III details results of experimental tests and section IV presents conclusions of presented proposal.

\section{Methodology}

Based on the previous introductory section and references consulted over development of this work, we identified some particular challenges in development of these kinds of systems for agriculture. The first is related with limited payload of UAV; since carrying additional sensors implies lower performance (hovering and maneuverability are affected with bigger payloads). The second issue is low flying autonomy (i.e. the AR Drone provides up to 15 minutes). Another difficult topic is robot configuration, as they usually consider optimal environmental conditions (like low wind speed, flat-shaped crops, and sunny days) for flights. Finally, the last challenge is the limited range of commercial route planners as a result of their manual operation; therefore, area, time, and number of pass points are not specified. In the following subsections, we describe the planned stages to achieve successful development of the proposal.

\section{A. Problem formulation}

Remote sensing with UAVs surpasses restrictions presented in traditional sensing in topics related with costs and multiple sensors handling; this allows gathering of detailed information related with physical chemistry variables at any time and place. Nevertheless, sensing based on aerial vehicles is limited by flying time and information losses given system failures. Hence, our approach is oriented to achieving implementation of a low-cost system to monitor spatial and temporal variability of crops through images ( FIGURE 1). The system must obtain trustworthy information from the studied crop, so, it is necessary to consider features like geography and the flight time of the AR Drone.

To address these problems, we pursue three particular objectives: adjusting the platform to crop features, i.e. optimizing the AR Drone positioning in open environments; obtaining complete crop information through route planning considering quadcopter limitations; and optimizing the system in order to gather useful images while bearing in mind previous items.

\section{B. Remote sensing system architecture}

The planned objectives in our approach agree with 
the conclusions presented by Vijay $\mathrm{Ku}$ mar, one of the first promoters of research with quadcopters. Kumar states that positioning estimation and task planning are the biggest challenges of applications with quadcopters. This is since Euler's aerodynamic model (which considers six degrees of freedom) is an approximation that does not involve interaction between engines and external forces; producing uncertainties in controllers and algorithms designed for missions planning. As a result of that, we present an architecture consisting of three development layers, which includes

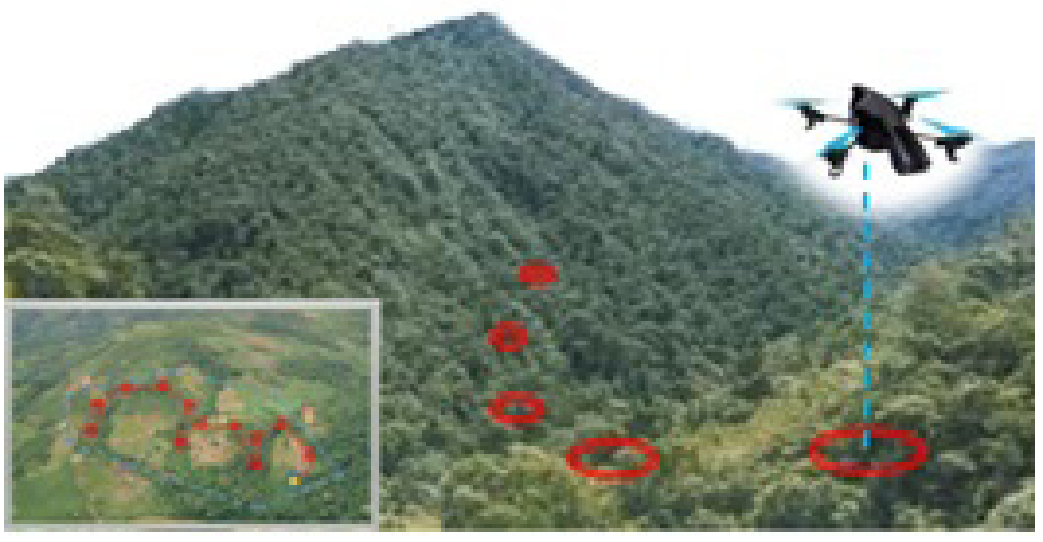
reactive and deliberative behaviors of $\mathrm{UAV}_{\mathrm{s}}$ to obtain optimal navigation. The design presented in Figure 2 is susceptible to possible changes inherent to implementation; it is also structured considering hybrid control architecture for mobile robots (Arkin, 1990).

\section{Reactive layer}

This layer faces challenges related with robot positioning in open fields and its adaptation to agricultural crops. To face this, we evaluate the main positioning techniques of quadcopters. Relative positioning is based on linear controllers for inertial movement and altitude, i.e. Proportional Integral Derivative (PID) (Li \& Li, 2011), Linear-Quadratic Regulator (LQR) (Guclu $\&$ Arikan, 2012) or combinations of PID and complex controllers, e.g. the Extended Kalman Filter (EKF) (Tanveer, Hazry, Warsi, \& Joyo, 2013). Limitations with these approaches rely on positioning based only on inertial movement unit is not functional in open environments. For positioning in external areas, GPS receivers should integrate with the inertial movement unit, achieving geographic location. Nonetheless, the position estimate depends on signal quality and it is not recommendable if high accuracy is needed (Tailanian, Paternain, Rosa, \& Canetti, 2014). Another option to manage the AR Drone positioning is by using simultaneous location and mapping techniques with a frontal camera. Still, the high computational complexity needed restricts its adoption for the presented prototype.

As noted before, accuracy search in external positioning concludes in a strategy that combines altitude sensors with GPS receivers. Moreover, even if this approach entails errors due to atmospheric conditions, academic literature shows that it is possible to obtain errors as low

\section{B) Arquitectura del sistema de teledetección para cultivos agrícolas}

Los objetivos planteados por la propuesta están en línea con las conclusiones a las que ha llegado Vijay Kumar, uno de los famosos promotores de investigación con cuadricópteros. Kumar declara que la estimación del posicionamiento y la planificación de tareas son los mayores retos de las aplicaciones futuras con cuadricópteros, ya que el modelo aerodinámico de Euler, que considera 6 grados de libertad, es una aproximación que no involucra la interacción entre los motores y las fuerzas externas ejecutadas sobre los propulsores; generando incertidumbre en los controladores y en el diseño de los algoritmos para la planificación de misión. Desde el anterior escenario se presenta una arquitectura con tres capas de desarrollo que integra comportamientos reactivos y deliberativos del robot aéreo para una óptima navegación. El diseño de la Figura 2 es susceptible a posibles cambios inherentes a la implementación y está estructurado considerando una arquitectura de control hibrida para robots móviles (Arkin, 1990).

\section{Capa reactiva}

Esta capa enfrenta el reto del posicionamiento del robot en espacios abiertos y la adaptación a los cultivos agrícolas. Para abordarlo son evaluadas las principales técnicas de posicionamiento de un cuadricóptero. La primera de ellas es el posicionamiento relativo, el cual está basado en controladores lineales para los sensores de movimiento inercial y de altura como PID (Proportional-Integral-Deribative) (Li \& Li, 2011), LQR (Linear-Quadratic Regulator) (Guclu \& Arikan, 2012) o combinaciones de PID con controladores complejos, como por ejemplo, el Filtro de Kalman Extendido (EKF) (Tanveer, Hazry, Warsi, \& Joyo, 2013). La limitación con esta iniciativa es que el posicionamiento basado solo en la unidad de movimiento inercial no es funcional en entornos abiertos. Para posicionamiento en exteriores pueden ser integrados receptores GPS (Global Position System) a la unidad de movimiento inercial, logrando una localización geográfica. Sin embargo, la estimación de la posición depende de la calidad de la señal y no es recomendable si la aplicación requiere precisión en la altura (Tailanian, Paternain, Rosa, \& Canetti, 2014). Otra op- 
ción para el posicionamiento del AR Drone es usar técnicas de localización y mapeo simultaneo con la cámara frontal. No obstante, la alta complejidad computacional de esta alternativa, limita su adopción para el prototipo propuesto.

De acuerdo con lo anterior, la búsqueda de precisión en el posicionamiento para exteriores concluye en una estrategia que combine sensores de altura con receptores GPS. Y aunque esto implique errores debidos a las condiciones atmosféricas, la literatura evidencia que es posible obtener errores de 1 metro en altura y precisión del 90\% en longitud y latitud (Chee \& Zhong, 2013). Con un posicionamiento preciso del AR Drone sobre los cultivos, el siguiente paso es la adaptación del cuadricóptero al relieve. Para el caso particular se coloca la mirada en técnicas en control no lineal basados en lógica difusa ya que modela el mundo real de forma cualitativa y propone respuestas características, tal y como un ser humano lo declararía. Además la implementación de este tipo de técnica está ampliamente soportada por el sistema operativo ROS (Bayar, Akar, Yayan, Yavuz, \& Yazici, 2014).

El control difuso inicia con la recepción de datos de los sensores de una planta (plataforma), es decir la interpretación, el mundo local, para convertirlos en variables difusas, llamado proceso de fuzzificación, en cual se describen características de la planta a modelar, como por ejemplo: muy alto, bajo, muy bajo. El dato fuzzificado se lleva a un conjunto de reglas de comportamiento que crean un motor de inferencia. Dicho motor permite relacionar las variables difusas con los resultados esperados, resultando en salidas difusas, las cuales son nuevamente convertidas en valores reales en un proceso llamado defuzzificación. En ese orden, un control difuso permite modelar la planta con un conocimiento intuitivo de la plataforma y una descripción cualitativa de su comportamiento. En el caso particular del control de altitud se encuentran trabajos para vehículos submarinos, vehículos aéreos no tripulados y zeppelines, los cuales demuestran la eficiencia de la técnica y su flexibilidad para posibles combinaciones con PID y redes neuronales, entre otras (Jian-Guo \& Jun, 2008; Shengyi, Kunqin, \& Jiao, 2009; Mehranpour, Emamgholi, Shahri, \& Farrokhi, 2013).

La ejecución de esta capa reactiva requiere de un procesamiento complementario entre la plataforma y los sensores, que controle la altura y la velocidad, en conjunto con los datos del FlightRecorder, modulo GPS del AR Drone 2.0.

\section{Capa deliberativa}

Esta capa asume el objetivo de recolectar información considerando las limitaciones de la plataforma y el área de cobertura. El resultado esperado de esta etapa es la navegación eficiente del AR Drone en puntos geográficos sobre el cultivo, que evite daños en la plataforma y pérdida de información. Para obtener dichos puntos se pretende diseñar un planificador de ruta de cobertura. De acuerdo con la literatura, existe una navegación del robot móvil basada en sensores, llamada planificación local o una planificación global, que requiere de un área con límites y obstáculos conocidos para la navegación (Galceran \& Carreras, 2013). Con base en este preámbulo, es as 1 meter in altitude and accuracy up to $90 \%$ in longitude and latitude (Chee \& Zhong, 2013). With precise positioning of the AR Drone over crops, the next step consists of adopting a quadcopter for topography. For this purpose, we focus on non-linear control techniques based on fuzzy logic, since this tactic models the real world in a qualitative manner and it provides certain answers, just as human beings do. Furthermore, implementation of this technique is highly supported by ROS operating system (Bayar, Akar, Yayan, Yavuz, \& Yazici, 2014).

Fuzzy control starts with data reception from sensors in a plant (platform), i.e. interpretation of the real world. Data is transformed in fuzzy variables in a process called fuzzification, where it describes plant features (e.g. too high, high, too low plants, etc.). Fuzzy data now reaches a set of behavior rules, which create an inference engine. This engine allows data to be obtained regarding of relations between fuzzy variables and expected results; emerging in fuzzy outputs, which are converted in real values in defuzzification. Hence, fuzzy control permits plants modeling with platform intuitive knowledge and qualitative description of their behavior. For the particular case of altitude control, we found projects results for submarine vehicles, UAV, and zeppelin type vehicles; these research projects demonstrate efficiency of fuzzy control technique and its adaptability to operate with PID combinations and neural networks, among other (Jian-Guo \& Jun, 2008) (Shengyi, Kunqin, \& Jiao, 2009) (Mehranpour, Emamgholi, Shahri, \& Farrokhi, 2013).

Implementation of this reactive layer requires complementary processing between platform and sensors, being capable to control altitude and speed together with FlightRecorder data (GPS module of AR Drone).

\section{Deliberative layer}

This layer deals with objective related with obtaining of information considering platform limitations and coverage area. Expected results of this stage consist on efficient AR Drone navigation in geographic points over crops, avoiding potential damages and information loss. For obtaining these points, we pretend to design a coverage route planner. Regarding consulted literature, there is a mobile robot navigation based on sensors called local planning, and a global planning that requires a limited area with known obstacles for navigation (Galceran \& Carreras, 2013). Based on this information and due to project objectives, we choose to design a global planner, since sensors usage for crop explorations implies higher 
processing capabilities and, consequently, higher power consumption; reducing AR Drone flight time.

Even though global planners do not consider navigation in dynamic environments, they beforehand manage turns and longitude presented in routes. In order to achieve this management, general procedure points out in dividing coverage area in grids (i.e. approximate decomposition) or dividing it by exact decomposition (Pignon \& Choset, 1998). After that, points where UAVs pass are marked and, subsequently, they determine the coverage plan considering existing restrictions. Some authors consider strategies like the $\mathrm{A}^{*}$ algorithm, wavefront based algorithm, and expansion tree to find better coverage routes over crops. This layer evaluates at least two of these algorithms to define best coverage route depending on crop conditions. Implementation of this planner requires relationships between route points (given by route planner) with camera resolution present in UAV and selected flight altitude.

\section{Management layer}

The management layer is in charge of implementation of previous tasks and platform control at low and high levels. A low level implies signals captured in the local world, whilst a high level implies signals from worldwide. Low level management infers automatic aerial photography capture in referenced points, whereas high level assumes fulfillment of tasks in the appropriate time to maintain the AR Drone positioning and pre-established route.

\section{Results}

\section{A. Development tool}

The proposal presented in this document is now at an initial stage, we are updating tools such as the following, in order to progress in desired activities:

- Raspberry Pi B+ Model, which is the optional processing unit to handle data from altitude and GPS sensors. We chose this Small Board Computer (SBC) due to its low weight, broad documentation, and acceptable processing capacity.

- Robot Operating System (ROS), basis of coverage planner development, driver implementation, and connection with the AR Drone. We use Fuerte/Hydro ROS over Ubuntu 12.04.

- Gazebo and RVIZ visualization tool, free licensed software suites used to support simulation and validation of navigation and height control strategies. claro que para los propósitos del proyecto la elección será el diseño de un planificador global, ya que el uso de sensores para exploración de un cultivo implica un mayor procesamiento y, por tanto, mayor consumo de potencia, lo que reduce el tiempo de vuelo del cuadricóptero.

Si bien un planificador global no contempla una navegación en entornos dinámicos, gestiona previamente los giros y la longitud de la ruta, además de asegurar una cobertura completa. Para lograr dicha planificación generalmente el área de cobertura se divide por descomposición aproximada (cuadriculas o rejillas) o por descomposición exacta, técnica que ha evolucionado con la estrategia Boustrophedon (Pignon \& Choset, 1998). Con el área divida pueden ser relacionados los puntos por los cuales pasará el robot y determinar el plan de cobertura considerando las restricciones existentes. Para encontrar la mejor ruta de cobertura sobre cultivos, algunos autores han considerado estrategias como el algoritmo basado en frente de onda, el algoritmo A* y el árbol de expansión, entre otros. De todos ellos esta capa evalúa al menos dos algoritmos para definir la mejor ruta de cobertura en las condiciones de los cultivos. La implementación del planificador requiere relacionar los puntos de la ruta encontrada por el planificador, con la resolución de la cámara portada en la plataforma y la altura de vuelo seleccionada.

\section{Capa de gestión}

Esta capa ejecuta las tareas anteriores y controla las acciones de la plataforma a los niveles bajo y alto, considerando nivel bajo $\mathrm{s}$ las señales capturadas del mundo local y nivel alto al modelo del mundo global. La gestión a nivel bajo incluye la captura automática de fotografías aéreas en los puntos referenciados; a nivel alto asume la ejecución de tareas en el tiempo justo para mantener un posicionamiento del AR Drone y el seguimiento de una ruta prestablecida

\section{Resultados}

\section{A. Herramientas de desarrollo}

$\mathrm{El}$ sistema propuesto en el presente documento se encuentra en una etapa inicial en la cual se están actualizando herramientas para progresar en las actividades formuladas como:

- Raspberry Pi Modelo B+, unidad de procesamiento opcional para integrar los datos del sensor de altura y el GPS; los motivos que llevaron a la selección de esta SBC [Small Board Computer] son el peso liviano, la amplia documentación y la significativa capacidad de procesamiento.

- El sistema operativo para robots ROS (Robot Operative System), base para el desarrollo del planificador de cobertura, la implementación de controladores y la conexión con el AR Drone; para la implementación actual se utiliza ROS Fuerte/Hydro sobre Ubuntu 12.04.

- Gazebo y visualizador RVIZ, herramientas soportadas con licencia libre en cualquier versión de ROS, mediante la que se apoya la simulación y validación de las estrategias de navegación y control de altura. 


\section{B. Validación de plataforma y control de altura}

El cuadricóptero AR Drone cuenta con un sistema de navegación que integra: giroscopio de 3 ejes $(2.0000 / \mathrm{s})$, acelerómetro de 3 ejes (+/-50 mg), magnetómetro de 3 ejes (precisión $\left.6^{\circ}\right)$, sensor de presión (+/- $10 \mathrm{~Pa}, 80 \mathrm{~cm}$ a nivel del mar), sensor de ultrasonido para medición de altitud respecto del suelo y cámara QVGA vertical a $60 \mathrm{fps}$ para medición de la velocidad respecto del suelo. Esta tecnología de movimiento inercial permite maniobras de pilotaje más definidas y dinámicas, y controlar el vuelo con referencia absoluta y estimación dinámica del viento (magnetómetro). Las Figuras 3 y 4 comparan el comportamiento del AR Drone en entorno de simulación y en un entorno real controlado. En la Figura 3, la velocidad en x (rojo), y (azul), z (verde) se observan para una trayectoria corta en línea recta. En el entorno real se denota que las fuerzas externas incurren sobre el cuadricóptero en aproximadamente 25\% de error relativo; en la Figura 4 se denota en los experimentos un error relativo pequeño de alrededor del 10\% con respecto a los resultados simulados.

Con lo anterior se retoma la necesidad de mejorar la precisión en la navegación de la plataforma aérea sobre cultivos agrícolas. De esta manera, se selecciona una integración del posicionamiento geográfico, mediante receptores GPS para localización en el plano, y el control de la altura, mediante un sensor de presión. Las otras alternativas nombradas en la metodología son descartadas porque implican mayor carga

a)

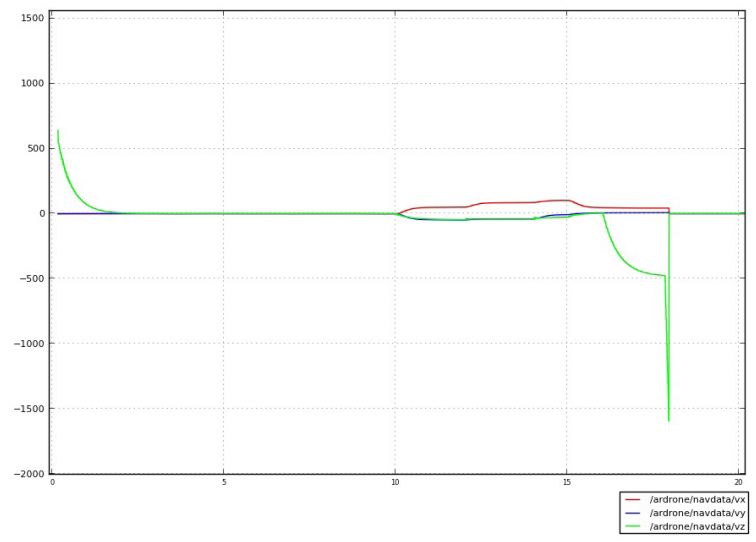

\section{B. Platform validation and height control}

The AR Drone quadcopter consists of a navigation system formed by a three-axis gyroscope, accelerometer, and magnetometer; besides of a pressure sensor, ultrasound sensor (for altitude data), and a QVGA camera (running at 60 FPS for speed measurements). This inertial movement technology allows better piloting maneuvers; besides flight control with absolute reference and wind dynamic estimation (through a magnetometer). In the following figures, we show a comparison between AR Drone behavior in simulation and real environments. Figure 3 shows the speed over the " $x$ " axis (in red), in " $y$ " axis (in blue), and in " $z$ " axis (in green) over a short straight-line trajectory. In the real environment, it is noticeable that external forces act on the quadcopter in approximately 25\% of relative error. In contrast, Figure 4 presents results of about 10\% of relative error in a simulated scenario.

Because of the previous results, we were forced to enhance the navigation accuracy of the aerial platform. Hence, we selected an integration of geographic positioning over GPS receivers to achieve localization and altitude control through pressure sensors. We discard the

b)

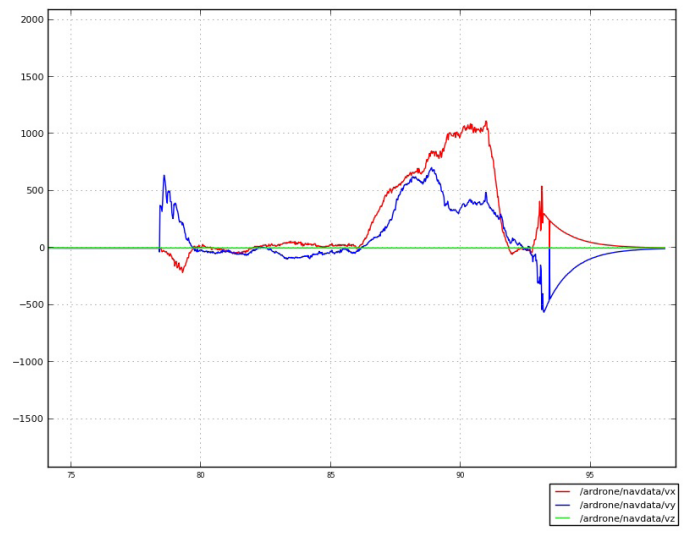

Figure 3. Speed in " $x$ ", "y", and "z" axes for (a) a simulated scenario and (b) a real and controlled environment / Figura 3. (a) Velocidad en x,y, $z$ para un entorno simulado y (b) para un entorno real controlado
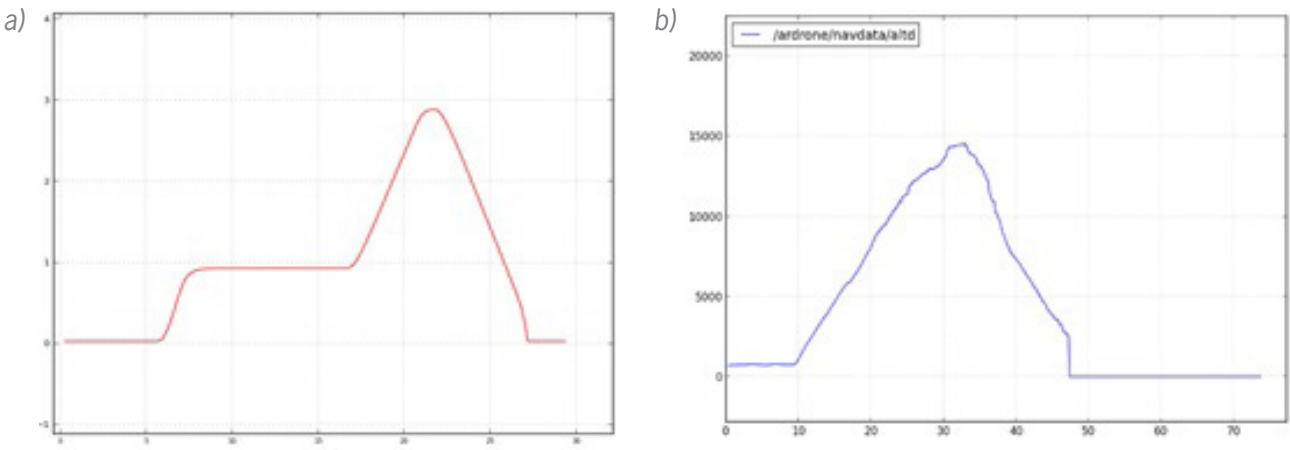

Figure 4. Altitude for (a) a simulated environment (up to 3 meters) and (b) a real scenario (up to 14 meters) / Figura 4. (a) Altura para un entorno simulado (hasta 3 metros) y (b) para un entorno real controlado (hasta 14 metros) 
other two methodologies mentioned earlier, since they imply bigger payloads and power to execute them. Control mechanism is based on fuzzy logic given its flexibility and adjustability to variable conditions.

In order to develop previous considerations successfully, the main reference is the research work made by (Mehranpour, Emamgholi, Shahri, \& Farrokhi, 2013). Contrary to the proposal presented by these authors, which basically consists in combining fuzzy control with PID control (fuzzy PID) over a quadcopter, our prototype relies control directly in inertial movement unit (i.e. in vertical speed). This, owing to Parrot $\AA$, does not supply support over drivers design. Fuzzy control design is based on analyses over transitory response (FIGURE 5) and it is desirable that it includes the following features:

- Total control of this first stage of development is a combination of implemented control over platform (generally PID controllers) and a fuzzy controller designed to handle platform in transitory response.

- In this transitory stage, altitude and speed must be controlled because, given AR Drone weight and materials, it is possible to loss accuracy in position due to combined movements (transverse and longitudinal).

- Speed control includes monitoring of pressure sensor (i.e. ultrasound sensor at low altitudes) and control over accelerometer and gyroscope. This trying to obtain smoother movements in transitory stages.

- Vertical speed control is result of altitude control; therefore, this phenomenon allows platform navigation considering topography and other details of studied area.

Figure 6 presents in-block control diagram for previous features, where " $h$ " is the data of altitude sensor and " $v$ " is a data structure including speed in every axis.

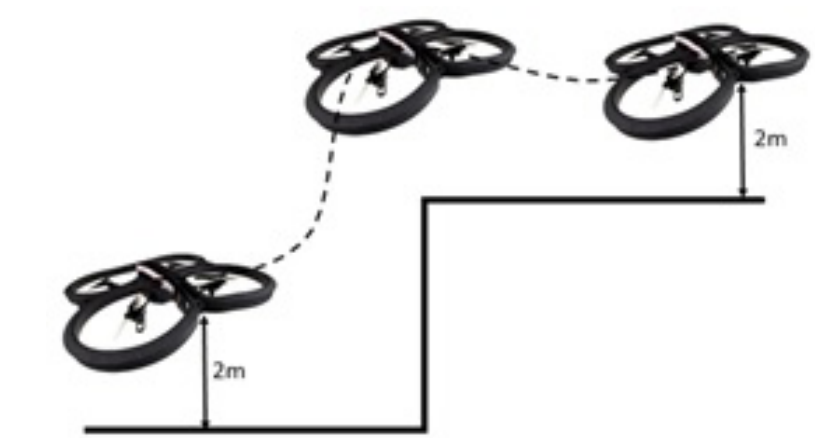

Figure 5. Transitory response / Figura 5. Respuesta transitoria

útil y potencia para ser llevadas a cabo. Para alcanzar la meta propuesta, el mecanismo de control de altura está basado en lógica difusa, ya que el control es altamente flexible y ajustable a condiciones cambiantes.

Para el desarrollo de lo mencionado se tiene como referencia principal el trabajo desarrollado por Mehranpour, Emamgholi, Shahri, y Farrokhi (2013). En contraste con la propuesta de los autores, de combinar el control difuso con el control PID ( Fuzzy PID) de un cuadricóptero, el prototipo diseñado para el proyecto evidencia el control directamente en la unidad inercial de movimiento, es decir, en la velocidad vertical, ya que el fabricante de AR Drone no brinda soporte del diseño de los controladores. El diseño del control difuso se basa en el análisis de la respuesta transitoria (FIGURA 5) y planea incluir las siguientes características:

- El control total para esta primera fase de la arquitectura de desarrollo es una combinación del control implementado en la plataforma (controladores PID u otros, no especificados por el fabricante) y un controlador difuso diseñado para tomar control de la plataforma en respuesta transitoria.

- En una etapa transitoria se debe controlar la altura y la velocidad ya que, por el peso y el material del AR Drone, es posible que en movimientos combinados (trasversales y longitudinales) se pierda precisión en la estimación de posición deseada.

- El control de la velocidad incluye el monitoreo del sensor de presión (o sensor de ultrasonido a bajas alturas) y el control actuante de acelerómetros y giróscopos; mediante esto se pretende lograr movimientos más suaves en estados transitorios.

- El control de la altura es el efecto directo del control de la velocidad vertical; esta idea pretende la navegación de la plataforma con respecto a las depresiones del relieve.

La Figura 6 describe el diagrama de bloques de control para las características plan- 


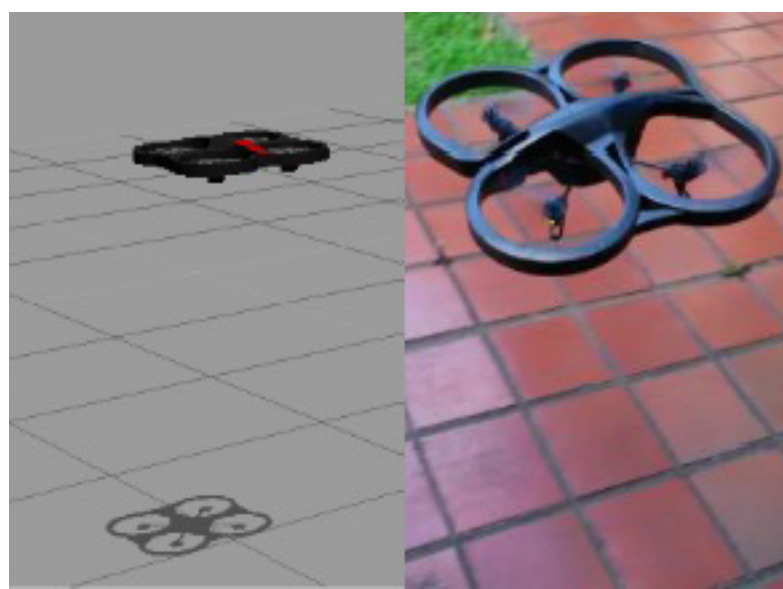

Figure 7. Simulation and real model of AR Drone quadcopter / Figura 7. Modelo de simulación y modelo real de AR Drone

teadas, en la cual h es el dato del sensor de altura y v es una estructura de datos que incluye la velocidad en cada uno de los ejes x, y, z.

\section{Simulación de algoritmos de planificación global de ruta}

Actualmente se está trabajando en la simulación del planificador de ruta utilizando paquetes de navegación del proyecto Hector_Quadrotor, debido a que es el paquete base de ROS para el control del AR Drone en el simulador Gazebo (FIGURA 7). En general los resultados no consideran las condiciones ambientales, ya que el objeto simulado como AR Drone en ROS no está soportado para este tipo de simulación. No obstante se encontraron soportes para enlazar Matlab con Hector_Quadrotor mediante plugins, con los cuales se puede evaluar el voltaje en los motores y crear un vector de viento.

Como primer paso hacia el planificador, se simulan algunos algoritmos para obtener la ruta más corta. Los algoritmos tienen como base la búsqueda en grafos para encontrar los nodos correspondientes a la ruta más corta y asumen un entorno conocido (mapa), el cual está divido en celdas cuadradas. Para su respectiva implementación se debe propagar primero el grafo sobre el mapa en el cual se mueve el cuadricóptero, para luego traducir los puntos de la mejor ruta encontrada al espacio de navegación en el simulador. Los algoritmos implementados se describen a continuación.

\section{Propagación de frente de onda}

Conocido también como BFS [Breadth-First Search] (Skiena, 1998), este algoritmo inicia en la raíz del árbol de nodos (meta) y explora todos los primeros nodos vecinos, antes de trasladarse a los vecinos del siguiente nivel, después de propagar los nodos asignando pesos, colocando cero para la meta, 1 para los primeros vecinos, y así sucesivamente, en incrementos de 1, hasta completar todo el grafo; la mejor ruta se establece realizando un retroceso secuencial desde el inicio hasta el destino. El algoritmo simulado en Gazebo considera los vecinos Von Neumann (Figura 8A).

\section{Algoritmo de Dijkstra}

Este algoritmo toma un punto inicial y la propagación de un grafo para encontrar la ruta más corta entre todos los no-

\section{Simulation of global route planning algorithms}

Currently, we are working on route planner simulation using navigation packages of the "Hector_Quadrotor" project, since it is the ROS base package for controlling AR Drone in Gazebo simulator (FIGURE 7). In general, simulation results do not consider environmental conditions because simulated object such as the AR Drone in ROS, do not support this kind of simulation in ROS. However, we found supports to link Matlab® with Hector_Quadrotor through plugins, capable of evaluating engine voltage and the creation of wind vectors.

One of the first steps towards planner is a simulation of algorithms to obtain the shortest route. The basis of these algorithms are graphs to find corresponding nodes to the shortest route; they assume known environment (map) divided into squared cells. For implementation, graph must propagate over the map whilst the quadcopter is moving. Subsequently this results in translation of points of best route to the navigation space in simulator. We briefly present a description of implemented algorithms.

\section{Wavefront propagation}

This is also known as Breadth First Search (BFS) (Skiena, 1998). This algorithm starts in the root of the node tree (goal) and it explores every first neighbor node before it moves towards the ones in the following level. During propagation, the algorithm assigns weights putting " 0 " for goal, "1" for first neighbors, and so forth increasing in unary steps until the graph is complete. The best route is established by performing backward moving from the start to the end. The simulated algorithm in Gazebo considers the Von Neumann neighbors (FIGURE 8A).

\section{Dijkstra algorithm}

This algorithm takes the initial point and graph propagation to find the shortest route between every connected node; unconnected nodes are considered as unreachable (infinite distance) (Dijkstra, 1959). It uses a "0" for initial node and "infinite" for not visited nodes. Whilst the route expansion continues, the algorithm creates a set of unvisited nodes. For the actual node, the algorithm considers every neighbor as unvisited and it calculates distances; then, this distance is compared with the assigned value to select the lower. When every neighbor node of the actual one are covered, this actual is marked as visited and it is not checked again. If the destination node has been marked as visited, or if lower distance between 
a)

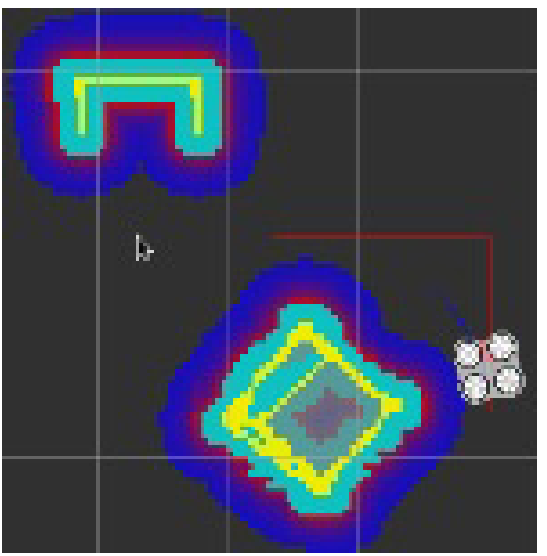

b)

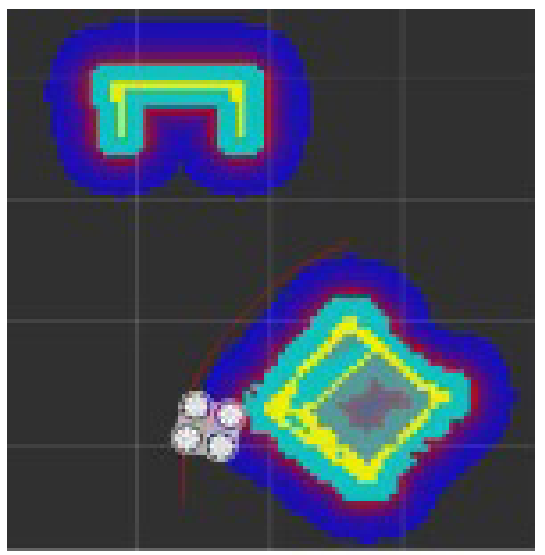

Figure 8. Route planning simulation in RVIZ: (a) route with wavefront propagation and (b) route with Dijkstra / Figura 8. Simulación de planificación de ruta en el visualizador Rviz: (a) Ruta con propagación de frente de onda y (b) Ruta con Dijkstra

Table 1. Shortest path algorithms comparison / Tabla 1. Comparación de algoritmos de la ruta más corta

\begin{tabular}{llll}
\hline Feature / Característica & $\begin{array}{l}\text { Wave-front / Frente } \\
\text { de onda }\end{array}$ & Dijkstra & A* \\
\hline $\begin{array}{l}\text { Number of visited nodes / } \\
\text { Cantidad de nodos visitados }\end{array}$ & High / Alto & Medium / Media & Low / Bajo \\
\hline $\begin{array}{l}\text { Number of visited nodes } \\
\text { more than once / Cantidad de } \\
\text { nodos revisitados }\end{array}$ & Mid / Medio & Low / Bajo & Low / Bajo \\
\hline $\begin{array}{l}\text { Number of nodes in the } \\
\text { shortest path / Cantidad de nodos } \\
\text { de la ruta más corta }\end{array}$ & High / Alto & Medium / Medio & $\begin{array}{l}\text { Medium / } \\
\text { Medio }\end{array}$ \\
\hline $\begin{array}{l}\text { Number of turns / Cantidad } \\
\text { de giros }\end{array}$ & Low / Bajo & High / Alto & High / Alto \\
\hline
\end{tabular}

dos conectados; los nodos no conectados son considerados a una distancia infinita (Dijkstra, 1959). El comportamiento de Dijkstra coloca un cero para el nodo inicial e infinito para los demás nodos marcados como no visitados. A medida que avanza la expansión de la ruta se crea un conjunto de todos los nodos no visitados. Para el nodo actual se consideran todos los vecinos no visitados y se calculan las distancias, luego se compara nuevamente la distancia con el valor asignado, para seleccionar el más pequeño. Cuando se han cubierto todos los vecinos del nodo actual, se marca el nodo actual como visitado y unvisited nodes is infinite, the algorithm ends (FIGURE 8в).

\section{A* algorithm}

It is one of the most used algorithms to determine routes from origin to destination points. $A^{*}$ implements heuristic processes in graph search, finding best route with lower computational costs compared with the previous ones (Hart, Nilsson, \& Raphael, 1968). Its implementation is based on graph propagation over studied area and adding value (i.e. distance) from start point to the rest of the nodes " $n$ ". This process defines a function $f(n)$ showed in (1) to evaluate which nodes are part of the route by considering actual cost until start point $(g(n))$ and the actual cost until goal $(h(n))$.

$$
f(n)=g(n)+h(n)
$$

Given the analyses of previous algorithms, we present a qualitative contrast based on requirements of designed architecture for remote sensing system. We present this comparison in Table 1. nunca será revisado de nuevo. Si el nodo destino ha sido marcado como visitado o si la distancia más pequeña entre los nodos del conjunto de nodos no visitados es infinita, entonces el algoritmo ha terminado (Figura 8B).

\section{Algoritmo A*}

Este algoritmo es uno de los más utilizados para determinar una ruta desde un punto origen a una meta. A* incorpora heurística para la búsqueda en grafos, encontrando la mejor ruta con un menor costo computacional que los anteriores algoritmos (Hart, Nilsson, \& Raphael, 1968). Para la implementación del algoritmo se realiza la propagación del grafo en el área de estudio, agregando el valor del costo o la distancia desde el punto de partida al resto de nodos n. Se define una función $f(n)$, descrita en la Ecuación 1, para evaluar los nodos que conforman la ruta, considerando el costo actual hasta el punto de inicio $g(n)$ y el costo actual a la meta $h(n)$.

$$
f(n)=g(n)+h(n)
$$

De acuerdo con el análisis de los algoritmos anteriores, se realiza una comparación cualitativa basada en los requerimientos de la arquitectura diseñada para el sistema de teledetección (TABLA $\mathbf{1}$ ). 


\section{Conclusiones}

La propuesta presentada en este artículo es el resultado de una previa revisión bibliográfica mediante la cual se identificaron brechas en investigación alrededor de los sistemas de teledetección con robots multi-rotor para agricultura de precisión. La solución de dichos desafíos se ve reflejada en el diseño de la arquitectura presentada, mediante la se busca brindar una alternativa para la adquisición de información de cultivos, con el mismo alcance de las técnicas tradicionales (satelital y aérea), pero con mayor acceso.

El desarrollo de la presente propuesta involucra la combinación de comportamientos reactivos y deliberativos, para conseguir que el cuadricóptero AR Drone se adapte a la condiciones del relieve y obtenga información completa de los cultivos. Para llevar a cabo dichas tareas se propone un control de la altura no lineal basado en lógica difusa, toma de fotografias aéreas del cultivo en tiempos y puntos predefinidos, y ejecución de un plan de cobertura eficiente desde una estación base.

Finalmente, para el establecimiento de la mejor ruta de cobertura se debe considerar que el AR Drone tiene un tiempo restringido de actividad y que se debe obtener información de grandes áreas (como es el caso de los cultivos agrícolas); por tanto, la selección del algoritmo de planificación de ruta de cobertura, está fundamentada en parámetros tales como como la ruta con la menor cantidad de giros, puntos predefinidos y revisitas, y una cobertura completa.

\section{Agradecimientos}

Los autores agradecen el apoyo recibido de la Vicerrectoría de Investigaciones de: la Universidad del Cauca - proyecto 4194 - Implementación de un sistema de sensado remoto de corto alcance para la obtención de información completa y precisa de un cultivo agrícola-; la Universidad Carlos III de Madrid - proyecto AgroCloud del programa RICCLISA-; y el Ministerio de Economía y Competitividad de España - proyecto TRA201 1-29454-C03-03. i-Support: Sistema inteligente basado en agentes de soporte al conductor-. S\&T

\section{Conclusions}

Our proposal presented in this document is the result of previous literature reviews, finding gaps in research projects related with remote sensing systems with multi-rotor robots for precision agriculture. We present one possible solution as the design of the presented architecture, which pursues assistance in acquisition of crop information with similar reach of traditional techniques (aerial and satellite) but gaining access.

Development of current proposal involves combination of several reactive and deliberative behaviors; this in order to correctly adapt AR Drone quadcopter to local topography and, subsequently, obtain complete crop information. In consequence, to carry out these tasks we propose a non-linear altitude control based on fuzzy logic, aerial photography in crops in specific moments and points, and execution of efficient coverage plan from base stations.

Finally, for establishment of best coverage route, it is important to consider that $\mathrm{AR}$ Drone has a restricted activity time, and system must cover areas as extensive as possible. Hence, selection of algorithm for planning route coverage is mainly based on route with less turns, less predefined points, less visits, and a complete coverage.

\section{Acknowledgement}

The authors would like to express gratitude for the support received from Research vice-Rectory of the Universidad del Cauca through project 4194: "Implementation of a short-range remote sensing system to acquire precise and complete information of rural crops". In addition, support received from Universidad Carlos III de Madrid, "AgroCloud" project of RICCLISA program, and financial support from Spain Ministry of Economy and Competitiveness (Project TRA2011-29454-C03-03. i-Support: Intelligent System Based on Driver Support Agents) is appreciated. $\mathbf{s}$.

\section{References / Referencias}

Agribotix (2015, May 11). Enduro. Retrieved from http://agribotix.com/quad-rotor-1/

ArduPilot autopilot suite (n.d.). APM Multiplataform Autopilot DRONECODE. (3DRobotics) Recuperado el 12 de Mayo de 2015, de http://ardupilot.com/

Arkin, R.C. (1990). Integrating behavioral, perceptual, and world knowledge in reactive navigation. Robotics and Autonomous Systems, 6(1), 105-122.

Bayar, V., Akar, B., Yayan, U., Yavuz, H. S., \& Yazici, A. (2014). Fuzzy logic based design of classical behaviors for mobile robots in ROS middleware. In Innovations in Intelligent Systems and Applications (INISTA), Proceedings (pp.162-169). IEEE.

Bongiovanni, R., \& Lowenberg-Deboer, J. (2004). Precision agriculture and sustainability. Precision Agriculture, 5(4), 359387.

Bristeau, P. J., Callou, F., Vissiere, D., \& Petit, N. (2011, August). The navigation and control technology inside the ar. drone 
micro uav. In Preprints of the 18th IFAC World Congress Milano (Italy) August 28 - September 2, 2011, (Vol. 18, No. 1, pp.1477-1484).

Chee, K., \& Zhong, Z. (2013). Control, navigation and collision avoidance for an unmanned aerial vehicle. Sensors and Actuators A: Physical, 66-76.

Dijkstra, E. W. (1959). A note on two problems in connexion with graphs. Numerische mathematik, 1(1), 269-271.

Galceran, E., \& Carreras, M. (2013). A survey on coverage path planning for robotics. Robotics and Autonomous Systems, 61(12), 1258-1276.

Gómez-Candón, D., De Castro, A., \& López-Granados, F. (2014). Assessing the accuracy of mosaics from unmanned aerial vehicle (UAV) imagery for precision agriculture purposes in wheat. Precision Agriculture, 5(1), 44-56.

Grenzdorffer, G., Engel, A., \& Teichert, B. (2008). The photogrammetric potential of low-cost UAVs in forestry and agriculture. The International Archives of the Photogrammetry, Remote Sensing and Spatial Information Sciences, 31(B3), 1207-1214.

Guclu, A., \& Arikan, K. B. (2012). Attitude and altitude control of an outdoor quadrotor [doctoral dissertation]. Atilim University: Ankara, Turkey.

Hart, P. E., Nilsson, N. J., \& Raphael, B. (1968). A formal basis for the heuristic determination of minimum cost paths. Systems Science and Cybernetics, IEEE Transactions on, 4(2), 100-107.

Jannoura, R., Brinkmann, K., Uteau, D., Bruns, C., \& Joergensen, R. G. (2015). Monitoring of crop biomass using true colour aerial photographs taken from a remote controlled hexacopter. Biosystems Engineering, 129, 341-351.

Jian-Guo, G., \& Jun, Z. (2008). Altitude control system of autonomous airship based on fuzzy logic. In Systems and Control in Aerospace and Astronautics, 2008. (pp.1-5). IEEE.

Ji-hua, M., \& Bing-fang, W. (2008). Study on the crop condition monitoring methods with remote sensing. International Archives of the Photogrammetry, Remote Sensing and Spatial Information Sciences, 37(B8), 945-950.

Joseph, G. (2005). Fundamentals of remote sensing. Hyderabad, India: Universities Press.

Li, J., \& Li, Y. (2011). Dynamic analysis and PID control for a quadrotor. Mechatronics and Automation (ICMA), 2011 International Conference on (pp. 573-578). IEEE.

Mehranpour, M. R., Emamgholi, O., Shahri, A., \& Farrokhi, M. (2013). A new fuzzy adaptive control for a Quadrotor flying robot. En Fuzzy Systems (IFSC), 2013 13th Iranian Conference on (págs. 1-5). IEEE.

Meier, L., Camacho, J., Godbolt, B., Goppert, J., Heng, L., Lizarraga, M., ... \& Tridgell, A. (2010). QGroundControl: Ground Control Station for Small Air-Land-Water Autonomous Unmanned Systems. Retrieved from: http://qgroundcontrol.org/

Pignon, P., \& Choset, H. (1998). Coverage path planning: The boustrophedon cellular decomposition. In Field and Service Robotics (pp. 203-209). London, UK: Springer.

Primicerio, J., Di Gennaro, S. F., Fiorillo, E., Genesio, L., Lugato, E., Matese, A., \& Vaccari, F. P. (2012). A flexible unmanned aerial vehicle for precision agriculture. Precision Agriculture, 13(4), 517-523.

Shengyi, Y., Kunqin, L., \& Jiao, S. (2009). Design and simulation of the longitudinal autopilot of uav based on self-adaptive fuzzy pid control. In Computational Intelligence and Security, 2009. (pp. 634-638). IEEE.

Skiena, S. S. (1998). The algorithm design manual: Text. New york, NY: Springer Verlag.

Sugiura, R., Noguchi, N., \& Ishii, K. (2005). Remote-sensing technology for vegetation monitoring using an unmanned helicopter. Biosystems Engineering, 90(4), 369-379.

Tailanian, M., Paternain, S., Rosa, R., \& Canetti, R. (2014). Design and implementation of sensor data fusion for an autonomous quadrotor. In Instrumentation and Measurement Technology Conference (I2MTC) Proceedings, 2014 IEEE International (pp.1431-1436). IEEE.

Tanveer, M. H., Hazry, D., Warsi, F. A., \& Joyo, M. K. (2013). Stabilized controller design for attitude and altitude controlling of quad-rotor under diisturbance and noisy conditios. American Journal of Applied Sciences, 10(8), 819-831.

Turner, D., Lucieer, A., \& Watson, C. (2011). Development of an Unmanned Aerial Vehicle (UAV) for hyper resolution vineyard mapping based on visible, multispectral, and thermal imagery. En Proceedings of 34th International Symposium on Remote Sensing of Environment (pp.1-4). ISPRS. Retrieved from http://www.isprs.org/proceedings/2011/ISRSE-34/211104015Final00547.pdf

Valente, J. (2011). An aerial robotic framework to address area coverage in precision agriculture practices [doctoral dissetation]. Universidad Politécnica de Madrid: Spain. 


\section{CURRICULUM VITAE}

Liseth Viviana Campo Received an Engineering degree in engineering physics from Universidad del Cauca, Colombia, in 2012, and presently is working towards a master's degree in telematics engineering from Universidad del Cauca, Colombia. Her current research interest is the application of quadcopters for precision agriculture. / Recibe el título de Ingeniera Física de la Universidad del Cauca, Colombia en 2012. Actualmente es candidata al título de Maestría en Ingeniería Telemática en la Universidad del Cauca (Colombia). Su interés en investigación es en desarrollo software para aplicaciones en la agricultura de precisión usando vehículos aéreos no tripulados.

Juan Carlos Corrales Received his Dipl-Ing and master's degrees in telematics engineering from the Universidad del Cauca, Colombia, in 1999 and 2004 respectively, and a Ph.D. degree in sciences, specialty computer science, from the University of Versailles Saint-Quentin-en-Yve- lines, France, in 2008. Presently, he is a full Professor and leads the Telematics Engineering Group at the Universidad del Cauca. His research interests focus on service composition and data analysis. / Recibe el título de Ingeniero y Máster en Ingeniería Telemática de la Universidad del Cauca (Colombia) en 1999 y 2004, respectivamente, y el título de Doctor en Ciencias, con especialidad en Ciencias de la Computación, en la Universidad de Versailles Saint-Quentin en Yvelines (Francia), en 2008. Actualmente es profesor titular y lidera el grupo de Ingeniería Telemática en la Universidad del Cauca. Sus intereses de investigación se enfocan en composición de servicios y análisis de datos.

Agapito Ledezma Espino Received an engineering degree in informatics from the Latin American University of Science and Technology (ULACIT), Panamá, in 1997, and a Ph.D. degree in sciences, specialty informatics engineering, from the University Carlos III of Madrid, Spain, in 2004. Presently, he is a full Professor and member of Control, Learning and Systems Optimization Group at the Universidad Carlos III de Madrid. His research interests focus on artificial intelligence and computational intelligence. / Recibe el título de Ingeniero en Informática de la Universidad Latinoamericana de Ciencia y Tecnología, ULACIT (Panamá, 1997) y el grado de Doctor en Ciencias con especialidad en Ingeniería Informática en la Universidad Carlos III de Madrid (España, 2004). Actualmente es profesor titular y miembro del grupo de Control, Aprendizaje, y Optimización de Sistemas, CAOS, en la Universidad Carlos III de Madrid. Su interés en investigación se enfoca en inteligencia artificial, minería de datos e inteligencia computacional. 